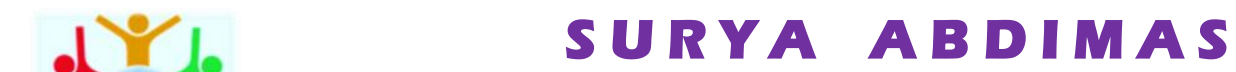

Vol. 5 No. 4 (2021) pp. 493 - 502

Available online at: http://jurnal.umpwr.ac.id/index.php/abdimas/index

p-ISSN: 2580-3492 e-ISSN: 2581-0162

\title{
fWorkshop Peningkatan Kompetensi Guru dalam Mereduksi Miskonsepsi IPA pada Siswa Sekolah Dasar
}

\section{Anatri Desstya $\bowtie$, Ika Candra Sayekti, Muhammad Abduh, Sukartono}

\author{
Universitas Muhammadiyah Surakarta
}

Jl. A. Yani, Mendungan, Pabelan, Kec. Kartasura, 57169, Jawa Tengah, Indonesia

I ad121@ums.ac.id $₫$ | DOI : https://doi.org/10.37729/abdimas.v5i4.1402 |

\begin{abstract}
Abstrak
Miskonsepsi IPA merupakan kondisi ketidaksesuaian antara pemahaman konsep IPA dari seorang pembelajar dengan konsep ilmiah dari para ilmuwan. Miskonsepsi IPA yang terjadi pada siswa SD merupakan tanggungjawab besar bagi para guru untuk bisa mengatasi dan mereduksinya. Dengan demikian pengabdian masyarakat ini bertujuan untuk meningkatkan kompetensi guru dalam mereduksi miskonsepsi IPA bagi siswa sekolah dasar. Sasaran mitra adalah guru sekolah dasar dari sekolah negeri dan swasta yang ada di wilayah Surakarta. Pengabdian ini dilakukan dengan tahap: persiapan, pelaksanaan, evaluasi dan tindak lanjut. Kegiatan pengabdian masyarakat ini dilaksanakan dengan metode workshop, ceramah, tanya jawab, praktikum, dan diskusi klinis. Hasil kegiatan pengabdian masyarakat ini menunjukkan bahwa terjadi peningkatan pemahaman tentang makna/ arti miskonsepsi, cara mereduksi, cara mendeteksi dan identifikasi miskonsepsi, jenis instrumen untuk mendeteksi miskonsepsi dari 16\% meningkat menjadi 94\%. Hasil yang kedua menunjukkan bahwa terjadi penurunan kondisi miskonsepsi IPA yang semula 90\% guru menjadi 30\% guru yang mengalami miskonsepsi. Hal ini menunjukkan bahwa kegiatan pengabdian masyarakat ini telah mampu meningkatkan kompetensi guru untuk mereduksi miskonsepsi pada siswanya. Namun, dalam menerapkan pemahamam yang telah diperoleh, perlu pendampingan bagi guru secara berkesinambungan terutama dalam menyusun instrumen dan melakukan deteksi miskonsepsi pada siswanya.
\end{abstract}

Kata Kunci: Workshop, Kompetensi guru, Miskonsepsi, IPA, Reduksi miskonsepsi

(c) (7) (8) This work is licensed under a Creative Commons Attribution-NonCommercial 4.0 International License

\section{Pendahuluan}

IPA merupakan salah satu muatan pelajaran yang di ajarkan di sekolah dasar. IPA merupakan materi pelajaran yang mengandung banyak konsep, sehingga membuka banyak peluang terjadinya miskonsepsi (Ibrahim, 2012). Menurut (A 'yun et al., 2017), miskonsepsi merupakan kondisi ketidakcocokan atas pemahaman konsep dengan konsep ilmiah yang dirumuskan oleh para ilmuwan dalam satu bidang kajian. Miskonsepsi IPA mulai dapat terjadi pada siswa sekolah dasar. Apabila miskonsepsi ini dibiarkan dan berlangsung lama, tanpa ada perbaikan, maka pemahaman konsep yang salah ini akan terbawa sampai ke jenjang pendidikan menengah dan pendidikan tinggi (Kucukozer, 2009; Nakhleh, 1992). Dampak selanjutnya, siswa mengalami hambatan yang besar dalam memahami materi (Yangin, 2014) sehingga sangat menentukan keberhasilan belajarnya (Clement et al., 1989). Selain itu, siswa membangun pengetahuan baru berdasarkan miskonsepsinya (Erman, 2017), keterampilan berfikir kritisnya menurun (Hughes \& Lyddy, 2013), serta kinerja akademiknya juga menurun (Kuhle, Barber, \& M. Bristol 2009). 
Menurut (Suparno, 2013), penyebab utama timbulnya miskonsepsi pada siswa adalah karena faktor siswa sendiri, guru, buku teks, konteks, dan cara mengajar. Dalam hal ini dapat diartikan bahwa miskonsepsi IPA yang terjadi pada siswa sekolah dasar disebabkan oleh pribadi siswa sendiri, guru sebagai pengajar dan pendidik di kelas, buku yang digunakan dalam pembelajaran, konteks yang di ambil sebagai contoh, serta cara mengajar guru.

Guru SD yang mengajarkan IPA merupakan guru kelas yang secara garis besar tidak berlatar pendidikan IPA, namun selama menempuh pendidikan telah diajarkan materi ke IPA-an selama empat sampai lima semester. Kondisi tersebut diperkuat dengan hasil penelitian yang dilakukan oleh (Desstya, Prasetyo, \& Suyanta 2019), bahwa dari 20 guru yang diobservasi, hanya 4 guru yang berlatar belakang pendidikan IPA. Hal ini memberikan perbedaan pemahaman yang cukup signifikan antara keduanya. Selanjutnya, dari sebaran tersebut, masih ditemukan guru yang mengalami miskonsepsi IPA sebesar 34,44\%.

Dapat dikatakan, guru yang berlatar belakang pendidikan IPA mempunyai pemahaman tentang konsep-konsep IPA yang lebih baik daripada guru yang bukan berlatar belakang pendidikan IPA (Desstya, Prasetyo, \& Suyanta 2019). Didukung dengan hasil observasi yang dilakukan pada tahun 2019 dan 2020, ditemukan bahwa siswa SD juga mengalami miskonsepsi IPA. Bahkan (Burgoon, Heddle, \& Duran, 2011) menyatakan bahwa miskonsepsi yang dialami oleh siswa SD mempunyai kesamaan dengan miskonsepsi yang dialami oleh gurunya. Hal ini merupakan sebuah bukti bahwa guru merupakan penyebab timbulnya miskonsepsi pada siswanya (Martinez et al., 2013).

Hal tersebut menunjukkan bahwa dengan adanya dampak negatif adanya miskonsepsi IPA pada siswa SD perlu adanya tindakan perbaikan dari salah satu sumber penyebabnya, yaitu dari faktor guru. Guru SD perlu mendapatkan perhatian yang besar agar mempunyai pemahaman yang lebih baik tentang konsep-konsep IPA sehingga ke depannya dapat melaksanakan pembelajaran yang lebih baik. Oleh karena itu, perlu dilakukan edukasi bagi para guru SD agar mempunyai pengetahuan tentang miskonsepsi, dan segala hal yang berkaitan dengan miskonsepsi, antara lain : cara mendeteksi, penyebab munculnya miskonsepsi, serta cara mereduksinya. Kegiatan ini dilaksanakan untuk meningkatkan kompetensi guru dalam upaya untuk mereduksi miskonsepsi IPA yang terjadi pada siswa SD.

\section{Metode}

Berdasarkan permasalahan yang ditemukan, maka pengabdian masyarakat ini dilaksanakan melalui beberapa tahap, yaitu persiapan, pelaksanaan, evaluasi dan tindak lanjut, dengan langkah sebagaimana disajikan pada Gambar 1. 


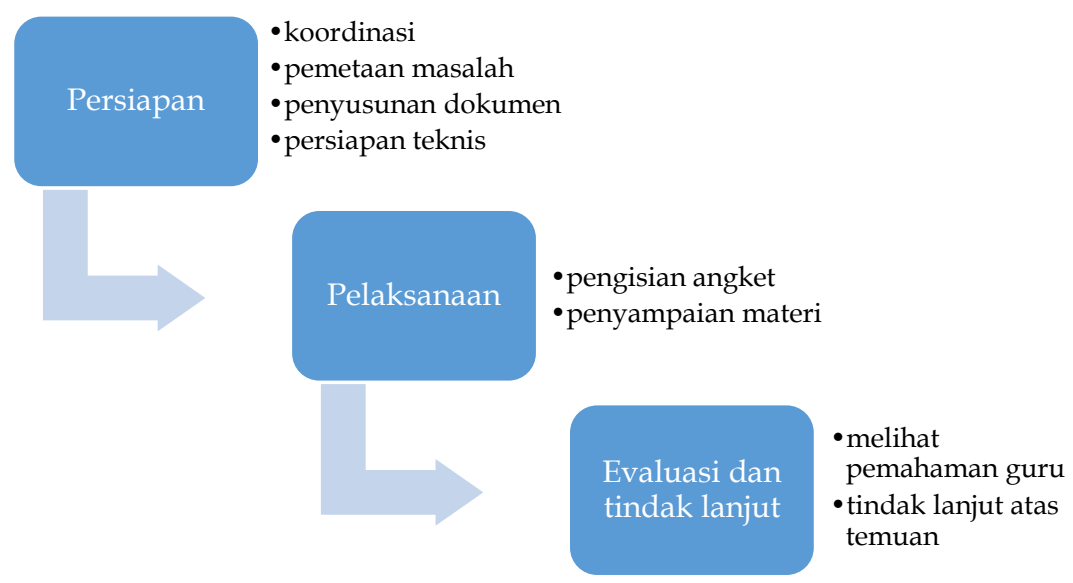

Gambar 1. Tahap Kegiatan Pengabdian Masyarakat

Pada tahapan persiapan dilakukan melalui beberapa kegiatan antara lain : (a) melakukan koordinasi internal yang dilakukan oleh 4 dosen dan 2 mahasiswa sebagai tim pelaksana, untuk merencanakan pelaksanaan secara konseptual dan operasional; (b) koordinasi eksternal yang dilakukan dengan pihak luar terkait, yaitu dengan kepala sekolah dasar negeri dan swasta yang tersebar di 5 kecamatan di wilayah Surakarta; (c) melakukan proses pemetaan permasalahan yang ditemukan di SD- SD di Surakarta; (d) penyusunan dokumen pelaksanaan pengabdian: surat menyurat, presensi, slide, materi, dan angket untuk menggali data; dan (e) persiapan teknis sosialisasi kegiatan pengabdian dan dokumentasi.

Tahap pelaksanaan kegiatan pengabdian dilakukan pada tanggal 01 Juli 2021, yang terdiri atas 2 sesi. Sesi pertama pengisian angket tentang pemahaman miskonsepsi IPA dan segala hal yang terkait. Sesi kedua dilakukan penyampaian materi kepada mitra (sekolah dasar) sasaran mengenai miskonsepsi IPA, dampaknya, cara mendeteksi, serta cara mereduksinya.

Tahap evaluasi dan tindak lanjut dilakukan dengan melihat kemampuan guru dalam menentukan pemahaman pada kategori miskonsepsi, memahami, menebak, atau tidak paham. Tindak lanjut dilakukan setelah menemukan beberapa permasalahan yang dihadapi oleh guru untuk selanjutnya dilakukan pendampingan secara berkelanjutan.

\section{Hasil dan Pembahasan}

Kegiatan pengabdian masyarakat ini dilaksanakan secara daring melalui platform Zoom Meeting pada hari Rabu, 01 Juli 2021, dari pukul 12.30 - 15.00. Peserta yang terlibat dalam kegiatan pengabdian masyarakat ini adalah 38 guru SD kelas atas yang tersebar di wilayah Surakarta. Secara bertahap, kegiatan pengabdian ini disajikan sebagai berikut.

\subsection{Kegiatan 1 (Pembukaan)}

Kegiatan Pengabdian Masyarakat ini di awali dengan pembukaan yang dilakukan oleh Ketua Program studi PGSD UMS. Dalam sambutannya menekankan bahwa kegiatan pengabdian masyarakat ini merupakan suatu bentuk Tri Dharma Perguruan Tinggi yang dilakukan secara kontinyu untuk mengembangkan profesionalisme guru-guru SD di wilayah Surakarta. 


\subsection{Kegiatan 2 (Pengisian Angket 1)}

Pada kegiatan ini, peserta diarahkan untuk mengisi angket tentang pemahaman mereka tentang miskonsepsi, sekaligus penerapannya. Butir- butir angket ini adalah: makna atau arti miskonsepsi, pengalaman dalam menggali miskonsepsi pada siswa, pemahaman tentang perbedaan instrumen deteksi miskonsepsi dengan instrumen yang lain, pemahaman tentang jenis-jenis instrumen deteksi miskonsepsi mulai dari two tier, three tier, maupun four tier. Dari keseluruhan item ini, diperoleh rerata pemahaman terkait miskonsepsi hanya 30\%. Hasil dari kegiatan ini bertujuan untuk mengetahui dan memetakan pemahaman guru tentang miskonsepsi dan segala hal yang terkait.

\subsection{Kegiatan 3 (Penyajian materi)}

Pada awal kegiatan ini, tim penyaji memberikan sebuah pertanyaan untuk mengetahui apakah guru sendiri mengalami miskonsepsi atau tidak. Hal ini dilakukan untuk memperkuat pernyataan yang disampaikan oleh (Suparno, 2013), bahwa tidak hanya siswa, namun guru juga mengalami miskonsepsi. Untuk mengetahui dan kemudian mereduksi terjadinya miskonsepsi yang terjadi pada guru, tim pengabdi menerapkan langkah-langkah yang mengacu pada sintaks model Conceptual Change Model (CCM), yaitu a) commit to an outcome, b) expose beliefs, c) confront beliefs, d) accommodate the concept, e) extend the concept, dan f) go beyond (Jain \& Luaran, 2020). Adapun penjelasan tentang CCM sebagai berikut:

a) Commit to an Outcome

Tahap ini dilakukan dengan memberikan pertanyaan dan mewajibkan guru untuk membuat prediksi tentang hasil yang akan diperoleh. Pertanyaan yang diberikan sebagai berikut: "Jika ada lima botol yang jenisnya sama, diisi dengan ketinggian yang berjenjang $3 \mathrm{~cm}, 8 \mathrm{~cm}, 13 \mathrm{~cm}, 18 \mathrm{~cm}$, dan $23 \mathrm{~cm}$, kemudian ditiup dengan intensitas tiup yang sama, maka botol manakah yang mempunyai bunyi paling tinggi?". Berdasarkan pertanyaan tersebut, peserta diinstruksikan untuk memprediksi hasinya.

b) Expose Beliefs

Langkah ini dilakukan di dalam forum meeting oleh tim pengabdi dengan memberikan kesempatan kepada pada guru untuk menyampaikan gagasan atau ide untuk menyingkap keyakinan mereka. Hal ini bertujuan untuk mengetahui keyakinan konsep dari satu peserta ke peserta yang lain. Dalam kegiatan ini, terdapat 5 guru yang mencoba untuk menjawab. Kelima guru memprediksi atas pertanyaan ini bahwa botol yang ketinggian airnya paling sedikit $(3 \mathrm{~cm})$ mempunyai bunyi yang paling tinggi. Beberapa alasan yang dikemukakan adalah karena botol yang airnya paling sedikit terdapat kolom udara yang lebih panjang, sehingga mengakibatkan bunyi dipantulkan lebih cepat sehingga terdengar lebih keras. Gagasan lain adalah botol dengan ketinggian air $3 \mathrm{~cm}$ mempunyai ruang kosong yang lebih besar, sehingga tekanan udara yang dimilikinya semakin besar. Tekanan udara yang besar akan memantulkan bunyi yang lebih tinggi.

c) Confront Beliefs

Pada tahap ini, tim pengabdi memberikan kesempatan kepada peserta lain untuk mendebat gagasan atau ide yang dikemukakan oleh peserat di tahap sebelumnya. Hal ini bertujuan untuk memperkuat keyakinan mereka masing-masing atas jawaban yang diperoleh. 


\section{d) Accommodate the Concept}

Langkah ini dilakukan untuk membuktikan kebenaran dari prediksi yang telah disampaikan oleh beberapa peserta. Tim pengabdi melakukan percobaan di mana peserta mengamati secara seksama bagaimana bunyi yang dihasilkan ketika 5 botol tersebut ditiup. Percobaan dilakukan sendiri oleh tim pengabdi, di mana peserta berada pada tempat yang tidak satu lokasi dengan tim pengabdi. Peserta diwajibkan untuk mengamati bagaimana hasil dari percobaan yang telah dilakukan. Berdasarkan pada hasil percobaan, peserta menyatakan bahwa dari kelima botol tersebut, yang paling tinggi bunyinya ketika ditiup adalah botol dengan ketinggian air yang paling tinggi. Alasan secara ilmiah adalah pada botol yang airnya paling tinggi, kolom udara yang tersisa paling rendah di antara botol lainnya. Jika panjang kolom udara kecil, maka panjang gelombang $(\boldsymbol{\lambda})$ yang dihasilkan juga rendah. Berdasarkan persamaan (1):

$$
f=\frac{v}{\lambda}
$$

dengan : $f=$ frekuensi $(\mathrm{Hz}) ; v=$ cepat rambat bunyi $(\mathrm{m} / \mathrm{s}) ; \lambda=$ panjang gelombang $(\mathrm{m})$. Jika panjang gelombang kecil, maka frekuensi yang dihasilkan lebih besar. Jika frekuensi besar, maka bunyi yang dihasilkan tinggi. Pembuktian tinggi rendah bunyi dengan persamaan di atas merupakan konsepsi ilmiah dari para ilmuwan. Jika dibandingkan dengan prediksi yang telah disusun oleh para guru sebelumnya, menunjukkan adanya perbedaan. Tim pengabdi menyimpulkan bahwa guru sendiri mengalami miskonsepsi. Hal ini dibuktikan dengan pemahaman konsep tentang tinggi rendah bunyi berbeda dengan konsepsi ilmiah dari para ilmuwan, lal ini sebagaimana yang dinyatakan oleh (Venkadasalam \& Ganea, 2018).

\section{e) Extend the Concept and Go Beyond}

Langkah ini dilakukan oleh tim pengabdi dengan memberikan contoh peristiwa sehari-hari yang konsepnya sama dengan tinggi rendahnya bunyi dalam kolom udara. Tim pengabdi memberikan contoh pada nada "do" dan "si" pada seruling yang dihasilkan saat ditiup, serta bunyi yang dihasilkan pada galon yang airnya dikosongkan. Dari contoh yang diberikan ini, peserta mampu memberikan penjelasan konsep yang benar.

Berdasarkan pengamatan dari tim pengabdi, semula peserta mengalami miskonsepsi pada konsep tinggi rendahnya bunyi. Setelah melalui beberapa tahap dari commit to an outcome sampai pada go beyond (sebagaimana kegiatan ini disajikan pada Gambar 2), peserta telah menjawab pertanyaan dengan konsep yang benar. Hal ini ditunjukkan adanya penurunan kondisi miskonsepsi dari yang semula 90\% guru mengalami miskonsepsi, kondisi akhir hanya 30\% yang mengalami miskonsepsi. Hal ini menunjukkan bahwa CCM efektif untuk mereduksi miskonsepsi. Sejalan yang disampaikan oleh (Cibik 2017), CCM merupakan salah satu model yang dapat menghilangkan miskonsepsi. Dari proses pendampingan yang telah dilakukan, tim pengabdi mengharap bahwa langkah-langkah dalam CCM ini bisa digunakan oleh peserta untuk mereduksi miskonsepsi yang kemungkinan terjadi pada siswanya. Contoh percobaan yang menerapkan CCM dapat disajikan pada Gambar 2. 


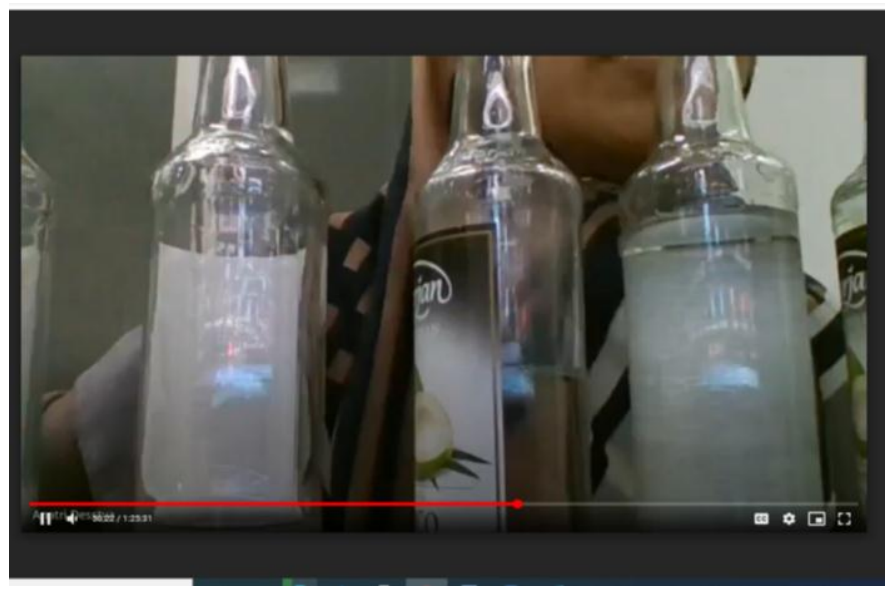

Gambar 2. Percobaan yang menerapkan tahap CCM

Setelah selesai melalui keenam tahap tersebut, tim pengabdi menyampaikan materi tentang dampak terjadinya miskonsepsi, sumber penyebab miskonsepsi, cara mendeteksi miskonsepsi, serta cara mengidentifikasi miskonsepsi menggunakan instrumen tertentu. Menurut (Yuberti, Suryani, and Kurniawati 2020); (Habiddin and Page 2019) dan (Saputra et al. 2020), terdapat beberapa jenis tes diagnostik miskonsepsi antara lain peta konsep dan tes berbentuk two tier, three tier dan four tier multiple choice. Berdasarkan jenis instrumen tersebut, guru di berikan pendampingan dalam mengidentifikasi miskonsepsi menggunakan acuan teori yang ditetapkan.

\subsection{Kegiatan 4 (Evaluasi dan Tindak Lanjut)}

Tahap evaluasi dilakukan dengan melihat kemampuan guru dalam mengidentifikasi pemahaman konsep menggunakan instrumen three tier multiple choice (Gurel, Eryilmaz, \& McDermott, 2015). Acuan yang digunakan untuk mengidentifikasi pemahaman konsep ini, sebagaimana disajikan pada Tabel 1.

Tabel 1. Kriteria pengelompokkan pilihan jawaban siswa pada three-tier multiple choice

\begin{tabular}{cccc} 
Tier pertama & Tier kedua & Tier ketiga & Kategori \\
Benar & Benar & Yakin & Paham konsep \\
Benar & Salah & Yakin & Miskonsepsi (false positif) \\
Salah & Benar & Yakin & Miskonsepsi (false negative) \\
Salah & Salah & Yakin & $\begin{array}{c}\text { Tebakan beruntun, kurang } \\
\text { percaya diri }\end{array}$ \\
Benar & Benar & Tidak yakin & $\begin{array}{c}\text { Kurangnya pemahaman } \\
\text { konsep }\end{array}$ \\
Benar & Salah & Tidak yakin & $\begin{array}{c}\text { Kurangnya pemahaman } \\
\text { konsep }\end{array}$ \\
Salah & Benar & Tidak yakin & $\begin{array}{c}\text { Kurangnya pemahaman } \\
\text { konsep }\end{array}$ \\
Salah & Salah & Tidak yakin & $\begin{array}{c}\text { Kurangnya pemahaman } \\
\text { konsep }\end{array}$ \\
\hline
\end{tabular}


Hasil pada kegiatan saat guru mencoba mengidentifikasi miskonsepsi adalah pemahaman yang dikatakan sangat baik jika dibandingkan dengan kondisi sebelum mengikuti pengabdian ini. Pada tahap evaluasi ini, guru kembali mengisi angket untuk mengetahui pemahaman tentang miskonsepsi yang telah disampaikan. Hal ini menunjukkan adanya peningkatan pemahaman dari $16 \%$ menjadi $94 \%$, sebagaimana di sajikan pada Gambar 3.

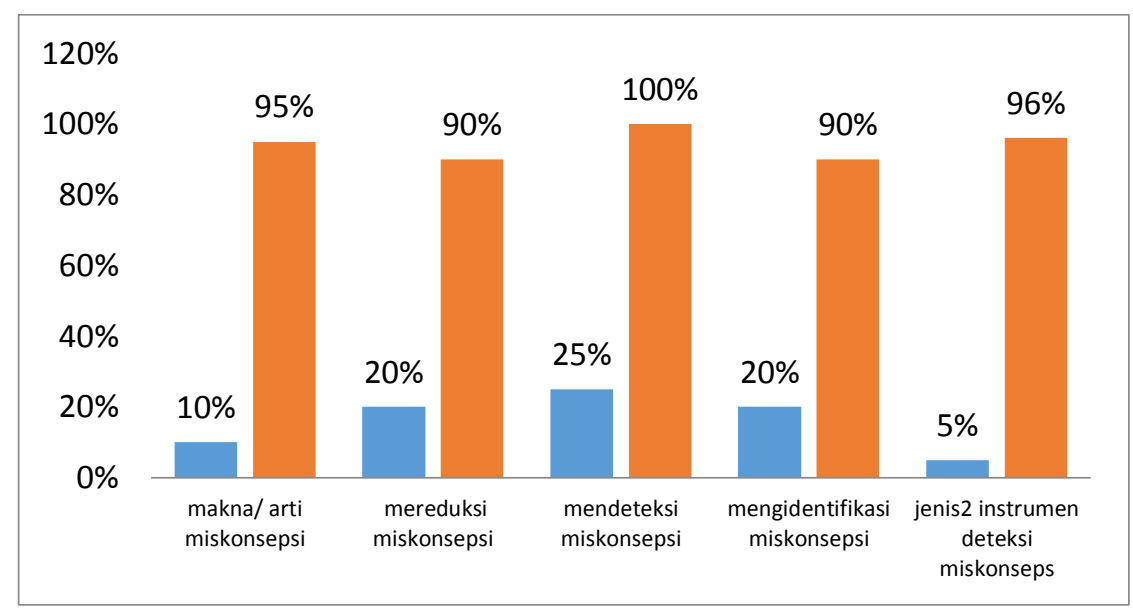

Gambar 3. Peningkatan Pemahaman Guru tentang Miskonsepsi

Berdasarkan data tentang penurunan prosentase guru yang mengalami miskonsepsi, serta data tentang peningkatan pemahaman tentang miskonsepsi dan segala hal yang berkaitan, menunjukkan bahwa tujuan kegiatan pengabdian masyarakat ini telah tercapai. Hal ini dibuktikan dengan adanya antusias dan semangat para guru dalam mengikuti kegiatan pengabdian masyarakat meskipun kegiatannya dilaksanakan secara daring dengan atmosfer akademik yang dapat dirasakan sebagaimana di sajikan pada Gambar 4.

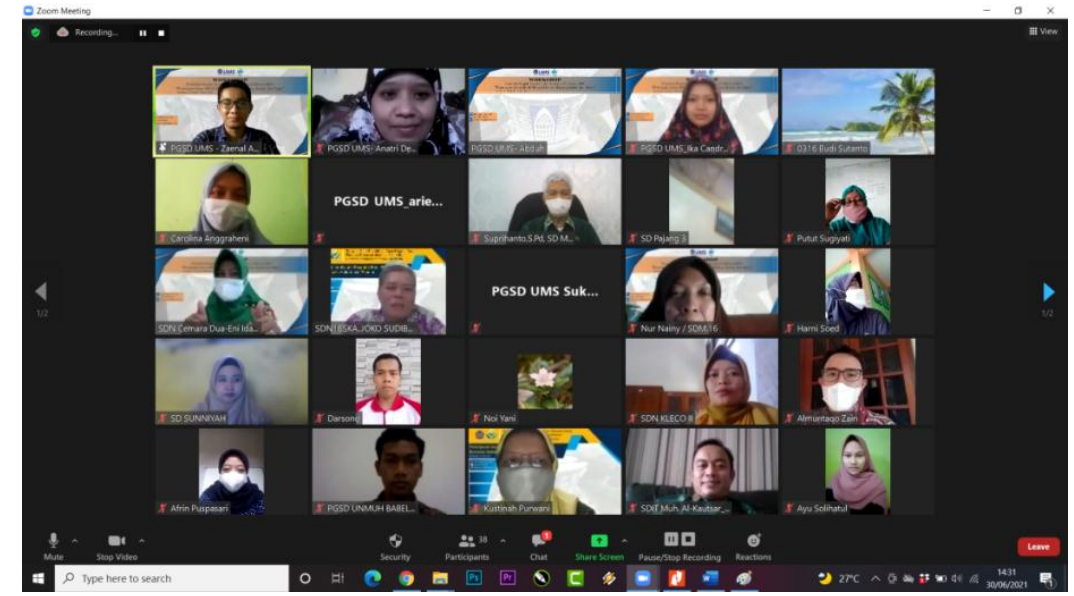




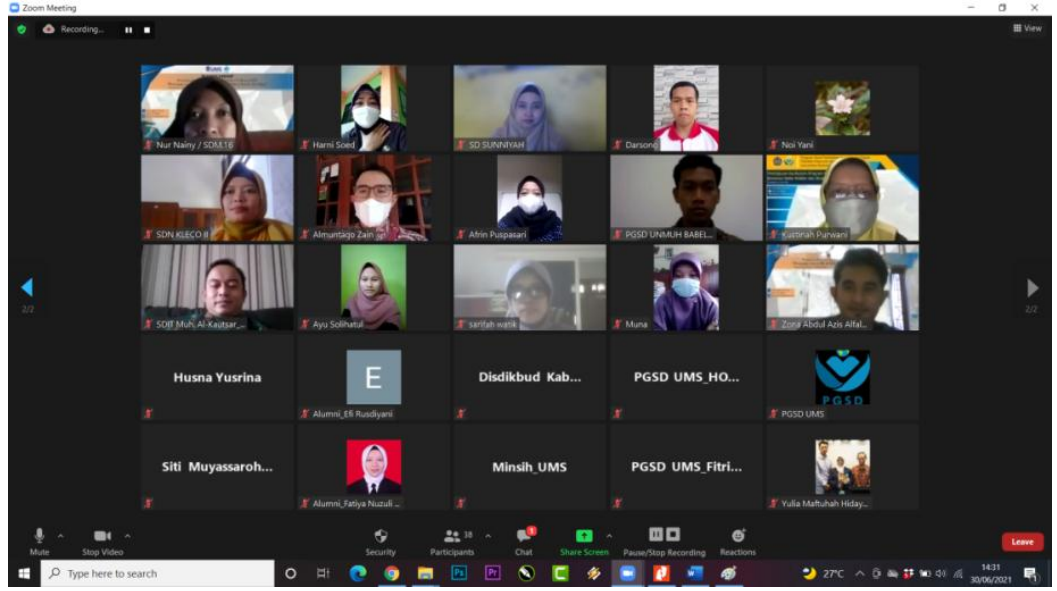

Gambar 4. Dokumentasi kegiatan pengabdian masyarakat

Kegiatan pengabdian masyarakat tidak hanya berhenti dalam forum ini, namun tindak lanjut yang dilakukan adalah a) memberikan proyek dan pendampingan bagi guru untuk menyusun instrumen deteksi miskonsepsi dalam bentuk two tier multiple choice, b) melakukan review terhadap instrumen yang dikembangkan, c) mendampingi guru dalam melakukan perbaikan instrumen dan mengujicobakannya kepada siswa, dan d) mendampingi guru dalam menganalisis hasilnya. Kendala yang dihadapi dalam kegiatan pendabdian ini adalah percobaan yang dilakukan secara daring oleh tim pengbdian dan terpisah dari para peserta, sehingga kevalidan hasil observasi perlu diperkuat kembali.

\section{Kesimpulan}

Hasil dari kegiatan pengabdian masyarakat ini mampu meningkatkan pemahaman guru tentang makna/ arti miskonsepsi, cara mereduksi miskonsepsi, cara mendeteksi dan mengidentifikasi miskonsepsi, serta pemahaman tentang jenis instrumen yang digunakan untuk mendeteksi miskonsepsi, dari 16\% meningkat menjadi $94 \%$. Selain itu, terjadi penurunan kondisi miskonsepsi dari yang semula $90 \%$ guru menjadi 30\% yang mengalami miskonsepsi. Hal ini menunjukkan bahwa kegiatan pengabdian masyarakat ini telah mampu meningkatkan kompetensi guru untuk mereduksi miskonsepsi pada siswanya. Namun, dalam menerapkan pemahamam yang telah diperoleh, perlu pendampingan bagi guru secara berkesinambungan terutama dalam menyusun instrumen dan melakukan deteksi miskonsepsi pada siswanya..

\section{Acknowledgement}

Ucapan terima kasih kami sampaikan kepada Universitas Muhammadiyah Surakarta yang telah memberikan support baik material maupun spiritual. Selain itu, kami sampaikan terima kasih kepada segenap tenaga pendidik baik dari sekolah dasar negeri maupun swasta di wilayah Surakarta yang telah menjadi mitra dalam kegiatan pengabdian ini. 


\section{Daftar Pustaka}

A 'yun, Kurroti, Sri Suyono, Saidna Poedjiastoeti, and Bin-Tahir Zulfiqar. (2017). "Reduction of Cognitive Conflict and Learning Style Impact towards StudentTeacher's Misconception Load." AIP Conference Proceedings 1868(030004). https://doi.org/10.1063/1.4995103.

Burgoon, Jacob N., Mandy L. Heddle, and Emilio Duran. (2011). "Re-Examining the Similarities Between Teacher and Student Conceptions About Physical Science.” Journal of Science Teacher Education 22(2): 101-14. https://www.tandfonline.com /doi/full/10.1007/s10972-010-9196-x.

Cibik, Ayse Sert. (2017). "Determining Science Teacher Candidates Academic Knowledge and Misconceptions about Electric Current." Educatioal Sciences: Theory \& Practice 17(3): 1061-90.

Clement, John et al. (1989). "Not All Preconceptions Are Misconceptions : Finding " Anchoring Conceptions ' for Grounding Instruction on Students ' Intuitions." International Journal of Science Education 11(5): 554-65. https://www.tandfonline.com/doi/abs/10.1080/0950069890110507.

Desstya, Anatri;, Zuhdan K Prasetyo;, and Suyanta. (2019). "Model Workshop 21stmisE Bagi Guru Sekolah Dasar Pada Muatan Pelajaran IPA.” Universitas Negeri Yogyakarta. http://eprints.uny.ac.id/id/eprint/68154.

Gurel, Derya Kaltakci, Ali Eryilmaz, and Lillian Christie McDermott. (2015). "A Review and Comparison of Diagnostic Instruments to Identify Students' Misconceptions in Science." Eurasia Journal of Mathematics, Science and Technology Education 11. Habiddin, and Elizabeth Mary Page. (2019). "Development and Validation of a Four-Tier Diagnostic Instrument for Chemical Kinetics (FTDICK)." Indonesian Journal of Chemistry 19(3): 720-36.

Hughes, Sean, and Fiona Lyddy. (2013). "Misconceptions about Psychological Science : A Review." Psychology Learning and Teaching 12(1): 20-31. www.wwwords.co.uk/ PLAT\%0A.

Ibrahim, Muslimin. (2012). "Prakonsepsi dan Miskonsepsi Pada Konsep IPA." : 1-47. Jain, Jasmine, and Johan Eddy Luaran. 2020. "Conceptualising Scientific Theory-Law Relationship among Pre- Service Teachers with Different Academic Abilities in Science." Asian Journal of University Education (AJUE) 16(3): 208-19.

Kucukozer, A. (2009). "Investigating Prospective Science Teachers' Misconceptions of Sound." Journal of Elementary Education Online 8(2): 313-21.

Kuhle, Barry X, Jessica Barber, and Adam S. M. Bristol. (2009). "Predicting Students' Performance in Introductory Psychology from Their Psychology Misconceptions." Journal of Instructional Psychology 36(2): 119-24. https://psycnet.apa.org/record/ 2009-11091-005. 
Martinez, Guadalupe, Angel Luis Perez, Maria Isabel Suero, and Pedro Jose. (2013). "Detection of Misconceptions about Colour and an Experimentally Tested Proposal to Combat Them." International Journal of Science Education 35(8): 1299-1324. http://dx.doi.org/10.1080/09500693.2013.770936\%0ADetection.

Nakhleh, M. (1992). "Why Some Students Don't Learn Chemistry Misconceptions, J." Chem Educ.

Saputra, Oka, Agus Setiawan, Dadi Rusdiana, and Muslim. (2020). "Analysis of Students' Misconception Using Four Tier Diagnostic Test on Fluid Topics." International Journal of Advanced Science and Technology 29(1): 1256-66.

Suparno, Paul. (2013). Miskonsepsi dan Perubahan Konsep Dalam Pendidikan Fisika. Yogyakarta: Gramedia Widiasarana Indonesia.

Venkadasalam, P Vaunam, and Patricia A Ganea. (2018). "Do Objects of Different Weight Fall at the Same Time? Updating Naïve Beliefs about Free Falling Objects from Fictional and Informational Books in Young Children." Journal of Cognition and Development 19(2): 165-81. https://doi.org/10.1080/15248372.2018.1436058.

Yangin, S. (2014). "Prospective Teachers' Misconception about Classification of Plants and Change in Their Misconception during Pre-Service Educatio." Journal of Baltic Science Education 13(3): 105-17. https://www.researchgate.net/ publication/287232118.

Yuberti, Yuberti, Yani Suryani, and Indah Kurniawati. (2020). "Four-Tier Diagnostic Test with Certainty of Response Index to Identify Misconception in Physics." Indonesian Journal of Science and Mathematics Education 3(2): 245-53. 